\title{
Developing social competence held in primary teacher inclusive education
}

\author{
Mega Iswari \\ Universitas Negeri Padang \\ ${ }^{*}$ Corresponding author, $\equiv$ e-mail: mega_iswari@yahoo.com
}

\begin{abstract}
This study aims to develop social competence in elementary school teacher who organizes the inclusion's educational system. As for the problems that often arise for teachers in schools is the lack of knowledge of teachers of children with special needs who become learners. Due to a variety of disorders experienced by learners. Thus it is necessary the development of social competence of teachers in order handling children with special needs who would require special-educatieducational inclusion. This type of research is the development of research carried out systematically, field tests, evaluated and improved to meet the prescribed criteria in terms of quality, effectiveness. The results of this study proved that through training can develop social competence elementary school teacher inclusion education in Padang.
\end{abstract}

Keywords: teacher's social competence, inclusion education, children with special needs

How to Cite: Iswari, Mega. (2017). Developing social competence held in primary teacher inclusive education. Couns-Edu: International Journal of Counseling and Education, 2(3): pp. 106-111. DOI: https://doi.org/10.23916/002017028430

(c) (i) This is an open access article distributed under the Creative Commons Attribution License, which permits unrestricted use, distribution, and reproduction in any medium, provided the original work is properly cited. (C2017. Indonesian Counselor Association (IKI).

\section{Introduction}

The teacher is an important factor in school education. Especially classroom teachers in primary schools that provide education inclusion. Because the teacher is a figure that has always been a role model for students (Widoyoko, E. P., 2009). For that a teacher should have competence in order to develop learners as a whole in accordance with the purpose of education. Competence is the ability to act, think and act consistently as an embodiment of knowledge, attitudes and skills possessed by learners (MONE, 2006: 57). Thus, competence is a set of knowledge and skills that must be owned by someone of teachers in performing their duties. Knowledge and skills can be acquired in pre-service education and / or training.

Government Regulation No. 19 of 2005 states that teachers are required to have some competence. Which includes; (1) pedagogical, (2) professional competence, (3) social competence and, (4) personal competence. Competence by Rothwell, (1996): intended as a character because the underlying success of a person having knowledge, skills, traits, abilities, behaviors and beliefs. Meanwhile, according Tarmansyah, (2009: 254) the competence of teachers in the school inclusion based on three main capabilities: (1) the ability of the public (general ability), (2) the ability of the base (basic abilities), and (3) special abilities (The specific abilities ).

In this study will be discussed is the development of social competence. Where is social competence is the ability of teachers as part of the public to communicate and interact effectively and efficiently with 
students, fellow teachers, fellow staff, fellow parents/guardians of students, and surrounding communities. In order to achieve the success of the learning process in schools is largely determined by social competence (Ashsiddiqi, H., 2012). Because teachers practice the learning process in schools, as a facilitator as well as a center of learning initiatives. Therefore teachers should always develop competency standards themselves and have a profession by mastering the material and learning strategies. In addition, teachers are also able to motivate students to study in earnest.

In the Directorate General of PMPTK Depdinas (2006: 7) social competence is a teacher's ability to communicate and get along with students, fellow teachers, staff, parents / guardians and the community. This activity should be done with productive communication with each other to do well, and inclusive education training for teachers can be run in accordance with the provisions, the social competence of teachers directly concerned will develop.

Social competence of teachers is the ability of a teacher to understand that he is an integral part of the community, teachers also need to be able to develop duties as members of society and citizens (Ashsiddiqi, H., 2012). The social skills consist of the ability to adapt to the demands of work and the environment. Teachers must be able to communicate well, whether orally or in writing speaking and even using cue through communication and information technology. Teachers must be able to interact effectively fellow learners and their parents and society.

Gullotta et al (1990) suggested some aspects of social competence, namely: (1) cognitive capacity, it is the underlying social skills in establishing and maintaining positive relationships interpeson. cognitive capacities include positive self-esteem, ability to look at things from the point of view of social and interpersonal problem-solving skills. (2) The balance between the need to socialize and privacy needs. the socialization needs of individuals and groups to engage in a relationship with another person. while the privacy needs is the need to be a unique individual, different, and free to act without the influence of others. (3) social skills with peers, an individual's ability to establish relationships with peers that do not have difficulty in adjusting to the group and can engage in group activities.

In the Ministry of Education (2009) is said to have a teacher of social competence in inclusive education where the teacher already has the knowledge and capabilities of: (1) communicate and interact effectively with learners of participants in the implementation of inclusive education, (2) communicate and interact effectively with fellow educators and education personnel., (3) communicate and interact effectively with parents / guardians of students and the community, (4) able to do his learning process, (5) able to perform well in class, and (6) are able to assessment of children with special needs.

Problems that occur in Inclusive Elementary School Padang, that teachers in primary schools do not have competence in implementing inclusive education, because they are not outside the Regular Education background and teachers have not been trained on inclusive education. Therefore, it is necessary the development of effective training models and innovative ways to improve the competence of teachers in inclusive education, teacher competence in the implementation of inclusive education in primary school Padang is still low, especially in the sosial.Untuk competencies necessary for inclusive education training for teachers. So the researchers conducted teacher training social competence is developed based on analysis of the needs of the teachers on the implementation of inclusive education in the city of Padang.

he government's commitment is clear again after the issuance of National Education Minister Regulation No. 70 Year 2009 on Inclusive Education. Article 7 states the implementation of inclusive education curriculum in 2013 with an integrated thematic accommodate the needs and abilities of learners according to their talents, interests, and potential. Article 8 mentions learning in inclusive education into account the principles of learning that are tailored to the characteristics of learners. especially for children with special needs who follow the inclusive education in primary schools in the city of Padang.

We realize Optimism success of the inclusive education becoming stronger with the inclusion of the government's role in its implementation so that the responsibility is not merely charged to the school organizers. Article 4 mandates the district / city government appoint at least one elementary and junior high school at the district level and one high school in the district / kota.Tugas other is to ensure the implementation of inclusive education and inclusive education resource available at a designated 


\section{COUNS-EDU •}

Vol.2, No.3, Month 2017

educational unit. The ministerial regulation also requires the district / city to provide at least one special guidance counselor at a designated educational unit. Also increase competence in the field of special education for teachers and other personnel in the educational unit of inclusive education providers. And the provincial government shall assist these tasks. Sapon-Shevin (2007). argues inclusive education as a system of education which requires that all children with disabilities served in schools nearby, in regular classes together friends of his age.

While Stainback and Stainback (1990: 73) argues that an inclusive school is a school that caters to all students in the same class. This school provides a good education program, challenging, but according to the abilities and needs of each student, as well as the help and support that can be provided by the teacher so that children succeed. Berit H. Johnsen and Meriam Skorten D. (2003: 288) states, that the principle of inclusive schools adapted to cause a huge demand for regular and special education teacher. It requires a shift from the traditional "teaching the same material to all students in the class", became teach each child according to their individual needs but in the kelas. While the setting, (O Neil, 1995) states that inclusive education as an educational service system which requires that all children with disabilities served at nearby schools, in regular classes together friends of his age. Therefore, emphasized the existence of a restructuring of the school, so that it becomes a community that supports the fulfillment of the specific needs of each child.

The curriculum used in the implementation of inclusive education in 2013, which basically uses the curriculum used in the regular school or apply in public schools. However, due to a variety of barriers experienced by learners with special needs vary widely, ranging from mild nature, moderate to severe, then the implementation on the ground, the regular curriculum needs to be modified (alignment) in such a way so as to suit the needs of learners. (Budiyanto, dkk..2010).

Modification (alignment) curriculum conducted by a team of developers in the school curriculum. School curriculum development team consists of: the principal, classroom teachers, subject teachers, special counselor, counselors, psychologists, and other relevant experts. If the curriculum modifications can not be applied for certain learners can develop a special curriculum called PPI (Individualized Education Program). Teachers make modifications to the learning strategy, the type of assessment, as well as other additional programs with reference to the needs of the students (special needs children). In this model there can be a special needs student who has a learning program based on the 2013 in the regular school curriculum and individualized education program (PPI). In this curriculum model teachers prepare individualized education program (PPI), which was developed together with the development team involving classroom teachers, special counselor, principal, parents, and other relevant experts.

Children with special needs are children who are significantly (significant) abnormalities, problems, and physical or irregularities, sensomotoris, mental-intellectual, social, emotional, behavioral, or combined in the process of growth / development compared to other children his age so they need special education services. (J. David Smith, 2009). Furthermore Mone (2006), states for the purpose of inclusive education children with special needs are grouped as follows: 1) .The with Impaired Vision, 2) .The Hearing Loss, 3) Child Physical Disorders Motor, 4) Gifted Child, 5) .The Impaired Property , 6). Slow Learning Child (slow learner). 7). Child Specific learning disabilities, 8). Children with Impaired Wicara.9). Children with Emotional and Social Disorder, and 10). Autistic Children.

The objectives of this study were: (1) To conduct training on inclusive education to regular teachers and teacher educators in elementary school special education Inclusive Padang. (2) To test the practicality and effectiveness of training to develop social competence organizes teachers in inclusive education in primary school Padang. (3) to provide insight to teachers about children with special needs and learning process, while the benefits of this research can be used as an education provider input inclusive in the improvement of science, particularly the field of inclusive education. and can develop competence and social competence, especially as principals and social competence of teachers in inclusive education, so that schools can implement inclusive education well. This will bring the impact of services to education for all children, not least children who have special educational needs. In addition, the learning facility will be available to suit the needs of all learners. 


\section{Method}

This type of research is the research and development (research and development). What is meant by research and development according to (WR Brog and Gall, MD., 1983) is "a process used to develop and validate educational products" or a process to develop and validate educational products ". Products in this context is not only relevant in a textbook or computer program, but rather in the form of methods or models of social competence development related to educational activities. Like, the training model should be developed regarding matters related to real life, which is more efficient, and realistic-objective. Gall and Borg (2002: 256) research suggests that the development of the model development is done in a systematic, field tested, evaluated, and refined to meet the criteria specified in terms of effectiveness, quality, or other standard specified.

The sample used in this study were elementary school teachers who have been teaching in inclusive education school at least two years, special educators and teachers who assist children with special needs in primary schools in organizing inclusive education. The total sample of 42 teachers, inclusive of 12 elementary schools in the city of Padang, which consists of 22 classroom teachers at the elementary school teachers and 20 special educators. Sampling technique was done by purposive sampling.

This form of training is formulated based on the study of the problems that occur in the field, especially with regard to social competence of teachers on the implementation of inclusive education in primary school Padang. So the researchers designed a training model with the aim to develop the competence of teachers in inclusive education in primary schools is limited to social competence. The model has been tested on a limited pilot group and a pilot group of users in order to determine the validity, practicability and effectiveness of the model.

William, B, Werther, (1989: 287), stating the steps used in the development of training programs are as follows: (1) needs assessment, (2) training and development objectives, (3) course content, (4) learning principles, (5) the actual program, (6) the skill knowledge ability of work, and (7) evaluation.

Training implies a more specific (specific), and related to work / tasks carried out by someone. While that meant practically was that respondents who already trained can be applied immediately and should be practical, (Fandi Tjiptono, et al, 1996). Hadari Nawawi (1997: 107), states that training is basically the process of providing relief for workers to master specific skills or help correct deficiencies in carrying out the work. The focus of its activities is to improve the ability to meet the demands of work in the most effective way to work at the present time. Ernesto A. Franco (1991), suggests an action training to improve the knowledge, skills an employee performing a specific job.

\section{Results and Discussions}

Operationally proven form of training can improve social competence of teachers in inclusive education, it is evidenced by the results of the test trainees before and after training given there is an increase on average, in which prior training was given an average score of 78.8571 with results $n=42$, whereas after training the average score increased to 87.5476. Similarly, the results of the analysis of the responses of the questionnaire instrument trainees stated that the training methods applied to help teachers to understand the training material about children with special needs and learning strategies that suit their needs and to improve the social competence of teachers in implementing inclusive education. so that teachers have the ability to communicate effectively with students, especially with special needs children in her class. also learners with students, fellow teachers and fellow educators, parents / guardians and the community.

Based on the research results proved that the training is inclusive of social competence is as the ability of teachers to communicate effectively with a bunch of students, fellow educators and fellow educators and parents / guardians and the community social. Competence is very important for a teacher other than the four other competencies such as pedagogical, profession, personality and leadership. From processing questionnaires and interviews of trainees stated that the training is not boring, so all excited to follow her teacher training, teachers feel enlightened, because so far the teachers in primary schools have never received training about as well as the methods used when training is very varied and tailored to adult 
learning, such as; using lectures, discussion, reflection, discussion, communication and interaction, watching movies, assignments.

Opinion was also supported by Lunandi (1982) and Soedomo (1989) said a conducive learning atmosphere for adults are as follows: (1) encouraging students to be active and develop talent, (2) an atmosphere of mutual respect and mutual respect, (3) an atmosphere of mutual trust and an open, (4) an atmosphere of self-discovery, (5) a non-threatening atmosphere, (6) the atmosphere acknowledges personal peculiarities, (7) the atmosphere allows differences, mistakes, and doubts, (8) allows participants students learn according to their interests, (9) allows learners to recognize and assess the strengths and weaknesses of personal, group, and community, (10) allows learners to grow in accordance with the values and norms that exist in society. The requirements mentioned above are applied to the training by using training methods that have been developed from the model, such as asking participants each presented a reflection of the learning materials, provide reinforcement to the active participants give their opinions and input and questions in learning. In addition to practical training, model has proven effective for improving the competence of teachers in implementing inclusive education. It is seen from the initial conditions for the conduct of teacher competence inclusive education can be seen from the results of the analysis of questionnaires that the pedagogical competence and social competence whereas less capable or low social competence and personal competence of teachers of teachers have high ability. Once tested all forms of training social competence in the category well or an increase. Thus, inclusive education training for teachers in primary school education has been implemented properly inclusion in developing social competence of teachers.

\section{Conclusions}

Developing social competency in teacher training can be done through a productive manner with good communication between teachers and learners, teacher communication with fellow teachers, and communication among parents / and society. Through inclusive education training was found to significantly develop the social competence of primary school teachers in implementing inclusive education. Because social competence is very important and has a strategy for organizing the educational process, therefore all teachers let own and control and be able to practice social competence, especially in children with special needs as well as other learners in primary schools inclusive education. Training activities are carried out in a practical and boring and not very fun for teachers as adult learning.

\section{References}

Agus Wibowo dan Hamrin, (2012) Menjadi Guru Berkarakter, Strategi $\quad$ Membangun kompetensi dan Karakter Guru, Yogyakarta: Pustaka Pelajar.

Ashsiddiqi, H. (2012). Kompetensi sosial guru dalam pembelajaran dan pengembangannya. Ta'dib, 17(01), 61-71.

Borg, W.R., Gall, M.D. (2003). Educational Reseach: An Introduction. London: Longman, Inc.

Budiyanto,(2005). Pengantar Pendidikan Inklusif Berbasis Budaya Lokal. Jakarta Depdiknas.

Depdiknas. (2004). Pengadaan dan Pembinaan Tenaga Kependidikan: Pedoman Penyelenggaraan Pendidikan Terpadu/Inklusi. Jakarta: Direktorat Pendidikan Luar Biasa

Depdiknas. 2004/2005. Program Pendidikan Khusus dan Pendidikan layanan Khusus: Pedoman Penyelenggaraan Pendidikan Terpadu/Inklusi. Jakarta: Direktorat Pendidikan Luar Biasa

Direktorat PLB (2004) Buku Paket: Pendekatan Pendidikan Inklusif, Dirjen Dikdasmen, Depdikbud: Jakarta

Miriam D.Skjorten. (2003).Pendidikan Kebutuhan Khusus; Sebuah Pengantar,Bandung:Unipub

Lunandi, A.G.1982. Pendidikan Orang dewasa sebuah uraian Praktis untuk Pembimbing, Penatar, Pelatih dan Penyuluh Lapangan . Jakarta: Asokadinata.

O'Neil,J. (1995) Can Inclusive Work? A Conversation With James Kauffman and Mara Sapon-Sevin.Educational Leadership 52(4)7-11.

UU RI Nomor 14 tahun 2005 tentang Guru dan Dosen

Undang-undang Nomor 20 tahun 2003 tentang Sistem Pendidikan Nasional.

Shevin, Sapon-, M. (2007). Widening the Circle. The Power of Inclusive Classrooms. Beacon Press, Boston.

Stainback, William. \& Stainback, Susan. (1990). Support Networks for Inclusive Schooling: Independent Integrated Education. Baltimore: Paul H. Brooks. 
Permendiknas RI Nomor 70 tahun 2009 tentang Pendidikan Inklusif Bagi Peserta didik yang Memiliki Kelainan dan Memiliki Potensi Kecerdasan dan/atau Bakat Istimewa

Widoyoko, E. P. (2009). Analisis pengaruh kinerja guru terhadap motivasi belajar siswa. 